\title{
Efficiency of use of high-strength concrete in reinforced concrete structures
}

\author{
Olena Kutsyk \\ Yurii Fedkovych Chernivtsi National University \\ Kotsyubinsky str. 2, Chernivtsi, Ukraine, 58012 \\ kutsikolena@gmail.com, orcid.org/0000-0002-4370-0221
}

The manuscript was received on 27.01.2018 and was accepted after revision for publication on 28.02.2018

DOI: 10.31493/tit1811.0301

\begin{abstract}
The analysis of the use of modern high-strength concrete in world practice is carried out. The advantages and disadvantages of highstrength concrete have been analyzed. The existing examples of the implementation of high-strength concrete in the world and their types and areas of application are considered. The prospects for using high-strength concrete in the construction industry of Ukraine are determined.Use of qualitative materials for the construction of supporting structures of high-rise building, and the construction of bridges, tunnels and other highly responsible buildings and structures. High-strength concrete with high durability, waterproof and gas tightness, corrosion resistance due to its homogeneous structure is efficient and promising for maintenance of all needs. In this work, samples of cubes, prisms, beams were developed and tested experimentally to determine and consider the efficiency of using high strength concrete in bending elements. In this article there are presented experimental results of tests, data on the selection of the effective composition of concrete mixture, and provided experimental samples with characteristic fractures. On the samples of the cubes that were presented, it can be seen the principles of destruction - the class C20 with normal destruction, and in the classes C60 and C80 there is a fragile nature of destruction. Also, the results of tests of prism fractures of classes C20, C60 and C80 were presented, where examples of fracture are also provided and elastic moduli of the samples were determined. The combined table showed cubic and prism strength, which shows the effectiveness of applying high-strength concrete in
\end{abstract}

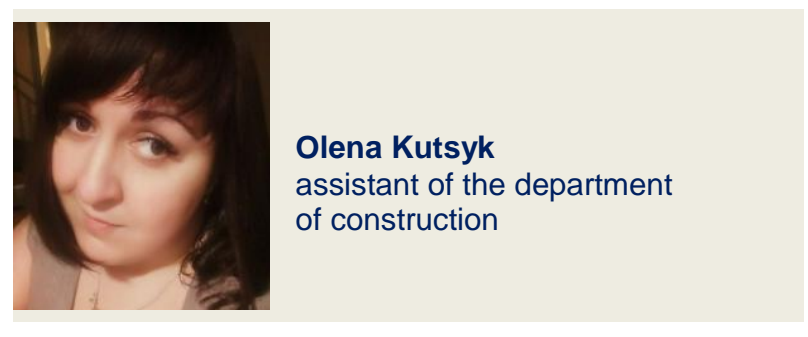

comparison with traditional concrete, since in concrete increase the compressive strength and the relative tensile strength, density, decreases the porosity and the structure is generally improved. The results of experimental studies of durability and crack resistance of reinforced concrete beams made of high-strength concrete are presented and compared with beams of ordinary concrete.

Key words: High strength concrete, plasticity, strength, crack resistance, deflection, modulus of elasticity.

\section{INTRODUCTION}

Construction of high-rise buildings, engineering structures, bridges, tunnels and other structures requires the use of efficient building materials which must meet certain technical and economic requirements. Such material is high-strength concrete. High mechanical strength, corrosion resistance and resistance to aggressive environment, gas tightness and water resistance put high strength concrete beyond competition when compared to traditional concrete. 


\section{PURPOSE OF WORK}

In order to introduce new high-quality materials and implement into the construction industry, in this work was considered a relatively new material for Ukraine, which is not standardized, high strength concrete. Experimentally prove the effectiveness and envisage the spheres of application. All the peculiarities of high strength concrete manufacturing were considered, to provide the industry with everything necessary for widespread use in Ukraine.

\section{ANALYSIS METHODS OF EXTRACTION}

Modern construction is characterized by growth in the number of floors of buildings, while the load on bearing structures is increasing.

Currently, in European countries, high strength concrete includes concrete mixtures with a compressive strength of 60 to $130 \mathrm{MPa}$. Such concretes are manufactured strictly according to the developed norms and rules that are established in the normative documents of various advanced countries. Applying the grain size of the binder to 600 microns and reducing the water-cement ratio to 0,15 , the concrete strength is reached to 200 $\mathrm{MPa}$. In this case they speak of heavy-duty concrete.

For the first time, the term "high-strength concrete" was used in 1929 in the United States, where new concrete and its components were investigated for the construction of highrise buildings, the compressive strength of which reached $130 \mathrm{MPa}$. In Europe, namely in Germany, the first high-strength concrete was obtained in the 40's of the last century. In
1966, in laboratory conditions concrete with a compressive strength of $140 \mathrm{MPa}$ was obtained, and in 1988, tubes of C85 grade concrete were manufactured in industrial conditions.

The first high-strength concretes were made using harsh mixtures, using special methods of sealing and autoclave hardening. It was found that in concrete the weakest component is cement stone. The strength in this case is proportional to the water-cement ratio. Therefore, its reduction was the first task of designers. The use of modern plasticizers makes it possible to significantly increase the strength characteristics of concrete.

\section{METHOD OF PREPARATION TESTS}

During the design and the preparatory stage, a number of experiments were carried out to select the optimal composition to ensure high strength, density and other physical and mechanical characteristics of high-strength concrete. The composition was considered using high-quality and available materials to ensure ease of production. All used materials were standardized. The main materials that were compared are: metakaolin and hyperplasticizer (STACHEMENT 2597).

In the course of the research, the amount of metakaolin use was considered in percentage terms to the amount of cement in the solution of $10 \%, 20 \%, 30 \%$ in the class of concrete C60. In the course of devastating tests, the results presented in Table 1 were obtained, that $10 \%$ of metakaolin from cement in a concrete mixture is the most optimal and stable; because with increasing amounts of metakaolin in the concrete mixture, an increase in the viscosity of the mixture was observed, but at the same time, the strength is lost because excessive

Table 1. Research of the optimal amount of metakaolin and strength at various compositions

\begin{tabular}{|c|c|c|c|c|c|c|}
\hline Series & $\begin{array}{l}\mathrm{M} \\
\%\end{array}$ & $\begin{array}{c}\mathrm{HP} \\
\%\end{array}$ & $\mathrm{~W} / \mathrm{C}$ & $\mathrm{C}$ & $\begin{array}{c}\text { Filler } \\
\mathrm{kg}\end{array}$ & $\begin{array}{c}\text { Strength } \\
\text { of cubes } \\
\mathrm{f}_{\mathrm{ck}, \text { cube }}, \mathrm{MPa}\end{array}$ \\
\hline $\mathrm{I}$ & 10 & \multirow{3}{*}{1,2} & \multirow{3}{*}{0,31} & \multirow{3}{*}{480} & \multirow{3}{*}{1800} & 65,4 \\
\hline II & 20 & & & & & 57,2 \\
\hline III & 30 & & & & & 43,1 \\
\hline
\end{tabular}




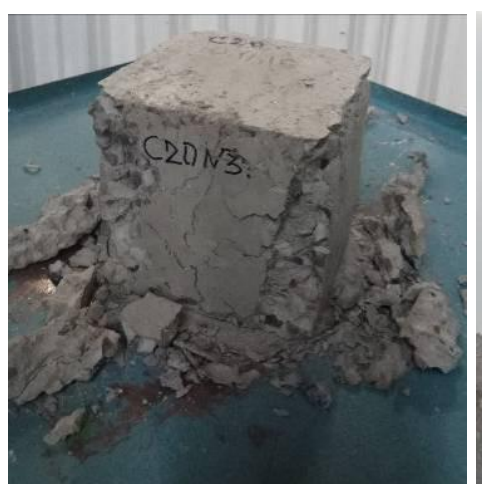

$a$

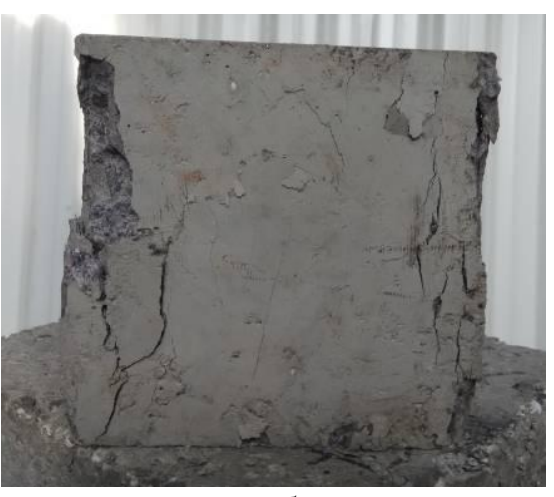

$\sigma$

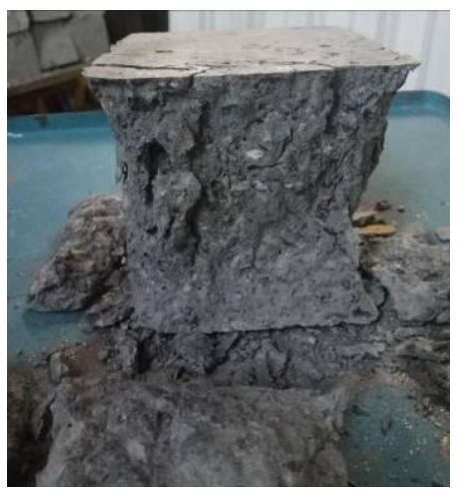

B

Fig.1. Character of the test of cubes: $a$ - concrete class C20; $b$ - concrete class C60; $c$ - concrete class C80

quantity negatively affect the strength characteristics.

The samples were made using hyperplasticizer (STACHEMENT 2597) and used in accordance with the technical recommendations for it.

Therefore, it was decided to make further samples to compare their characteristics in the classes C20, C60 and C80. For comparison, how metakaolin improves the characteristics of the properties of concrete in different classes and their work in structures, possibility of improvement and achievement of high-strength concretes of class $\mathrm{C} 80$.

In the course of the work, experiments were made in which the composition of concrete was first selected and their strength characteristics were investigated by testing. In Fig.1 it can be seen the nature of the destruction of various comparative classes of concrete, which consisted of the same materials, but in the calculated need for classes C20, C60 and C80. When examining and analyzing all samples, the following results were obtained: the class of concrete $\mathrm{C} 20$ cubes collapsed with an average strength of 31,45 $\mathrm{mPa}$, in Fig.1, $a$ we can see that the sample has collapsed in the middle and that it has normal destruction. At the same time in Fig. $1, b$ and $c$ the cubes of classes $\mathrm{C} 60$ and $\mathrm{C} 80$ are depicted, they already have a classical fragile destruction, which is accompanied by more vertical cracks. It was also discovered that the C20 class cubes were destroyed by adhesive, and in C60 and C80 disruptions occur along the adhesive substance with chips on the granite aggregate.

A test was carried out on the data given in the chart Fig.2 depicts the placement of longitudinal and transverse indicators that measured the deformations which were formed during the testing of prism measuring $100 \times 100 \times 400 \mathrm{~mm}$. This was done to check and analyze the movements in the body of prisms.

Testing prisms it can be said that the nature of the destruction of concrete class C20 is depicted in Fig.3, $a$ is normal that is found in all regulatory documents and therefore

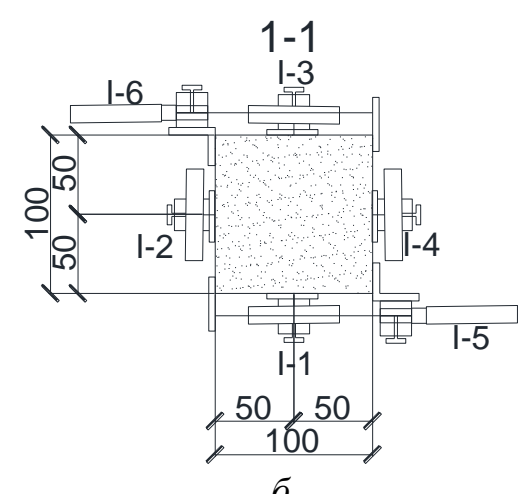

6

Fig.2. Prism test scheme: $a-$ the front view; $b-$ section $1-1$ 

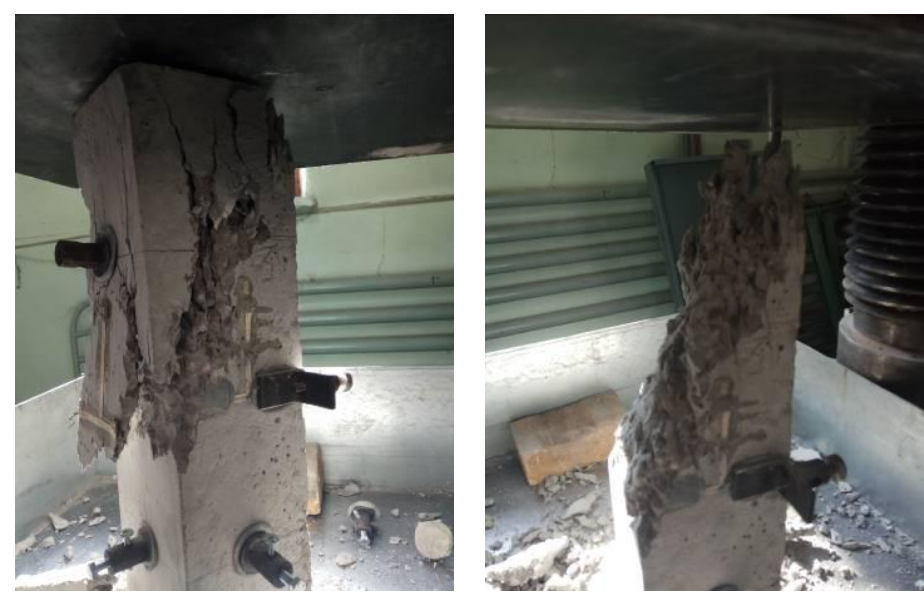

$a$
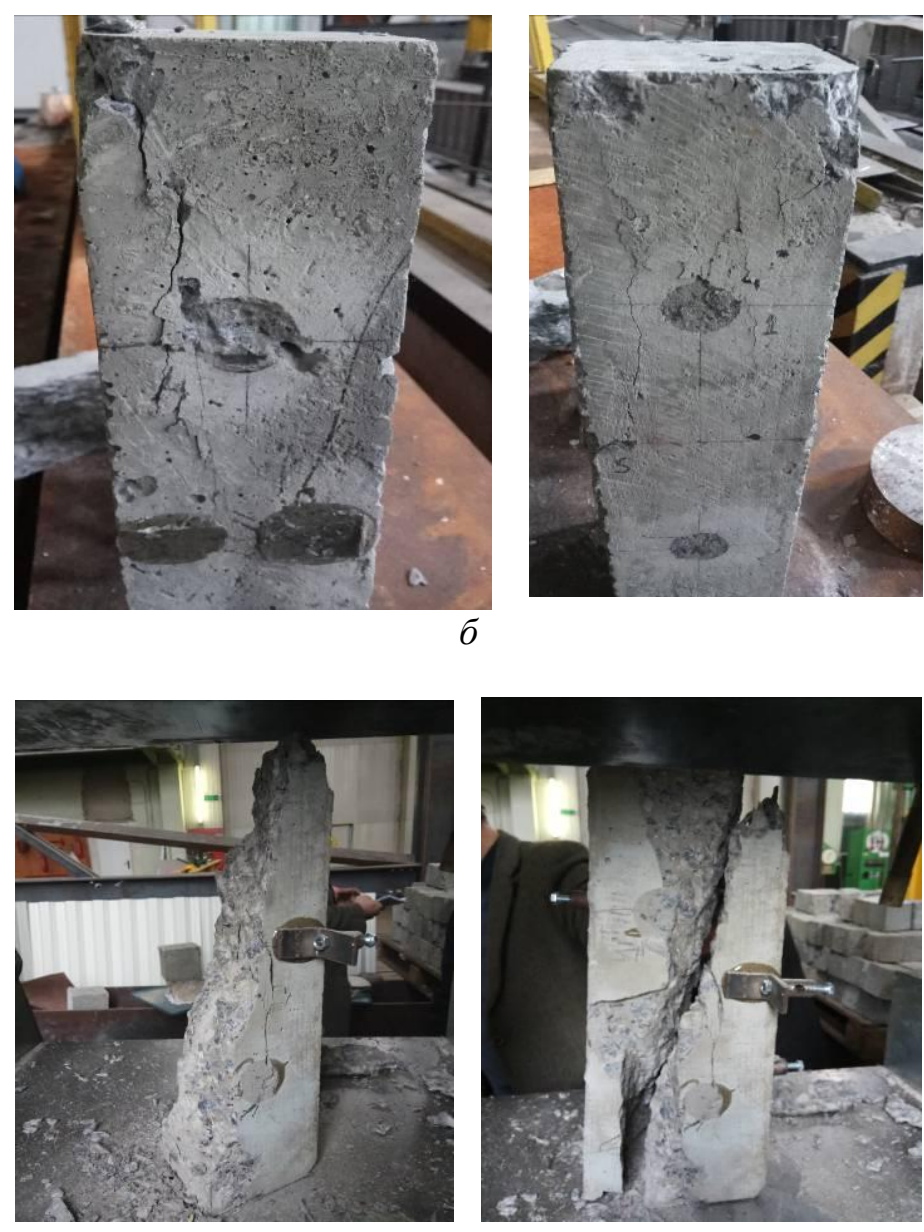

B

Fig.3. The nature of the prism test: $a$ - concrete class $\mathrm{C} 20$; $b-$ concrete class C60; $c$ - concrete class C80

metakaolin does not affect the nature of the destruction in conventional concretes, that is, those which are widely used, but increases the strength characteristics. In this case, concretes of class C60 and C80 depicted in Fig.3, $b$ and $c$ have a number of features that is during the experiment the test was accompanied by brittle fractures and with various destruction and breakdowns typical to high strengths. 
Experimental studies have shown that using high-strength concrete for supporting elements of frame-type buildings provides good seismic stability of structures. The cross-sectional dimensions of structural elements of highstrength concrete are less, which leads to a decrease in in its own weight and improvement of the economic efficiency of construction. The high strength of concrete is also effective for the construction of structures with prestress. This is ensured by the use of highstrength reinforcing rods and ropes, which significantly increases the rigidity of elements and their fracture resistance. Due to this prestressed reinforced concrete structures are used in large-span and overall structures.

The use of high-strength concrete with high density is effective for structures exposed to cyclic and explosive loads. Among the main features of high-strength concrete are water resistance and corrosion resistance that ensure the reliability and durability of reinforced concrete structures.

High-strength concrete has the following advantages:

- the use of typed formwork for the manufacture of columns in the factory production conditions, for various loads, the opportunity of manufacturing columns for all floors, which makes it possible to use highstrength concrete on lower floors in monolithic construction;

- when working on bending, there is a decrease in the working height of the crosssection or an increase of the bearing capacity of structures;

- reducing the consumption of concrete and armature and, accordingly, saving costs for transportation and installation of structures; earlier formwork and pre-compression; acceleration of the time of the initial strength set, which allows to start the exploitation of the element earlier;

- high density, water and gas tightness due to low content of capillary pores;

- the possibility of creating various crosssections of elements with increasing the span length of structures which are working on the bend;

- increased wear resistance;
- reduction of the cross-sectional dimensions of the elements, which reduces the expense for the formwork;

- resistance to aggressive environments due to high density.

However, with the undeniable advantages of high-strength concrete, it is worth remembering its drawbacks:

- the nature of the destruction of elements of high-strength concrete due to its high strength and rigidity is fragile, therefore, anticipation of special measures is required when designing and constructing structures from it to ensure reliable exploitation of buildings;

- self-sealing and cast mixtures of concrete tend to have a high shrinkage, the value of which can reach up to $0,8 \ldots 1,0 \mathrm{~mm} / \mathrm{m}$.

For the manufacture and production of highstrength concrete, the industry must use highquality materials, namely:

- thin-milled components.

- inert fillers of required fractions and purity;

- highly active and stable cement;

- modern plasticizing additives.

\section{METHOD OF PERFORMANCE OF BASIC TESTS}

At the Department of Reinforced Concrete and Stone Structures of the Kiev National University of Construction and Architecture, studies are carried out on the construction of high-strength concrete of the class C60...C80. The samples were made of concrete, consisting of: granite crushed stone (two fractions $5 \ldots 10$ $\mathrm{mm}$ and $10 \ldots 20 \mathrm{~mm})$, quartz sand $(0,95 \mathrm{~mm}$ grain size module), M500 cement, metakaolin additive, and hyperplasticizer (STACHEMENT2597), water ( $\mathrm{W} / \mathrm{C}=0,32)$. As a result of testing concrete cubes with an edge of 100 $\mathrm{mm}$, the maximum value of cubic strength is 96,8 MPa.

For experimental studies, three series of samples were used (four beams in each series). Beams $1200 \mathrm{~mm}$ long and $100 \times 50 \mathrm{~mm}$ cross section were reinforced in the stretched zone by two rods $\varnothing 12 \mathrm{~A} 400$, and in the compressed zone by one rod Ø5Vr-I (Fig.4). The transverse reinforcement $\varnothing 5 \mathrm{Vr}-\mathrm{I}$ is installed with a step 


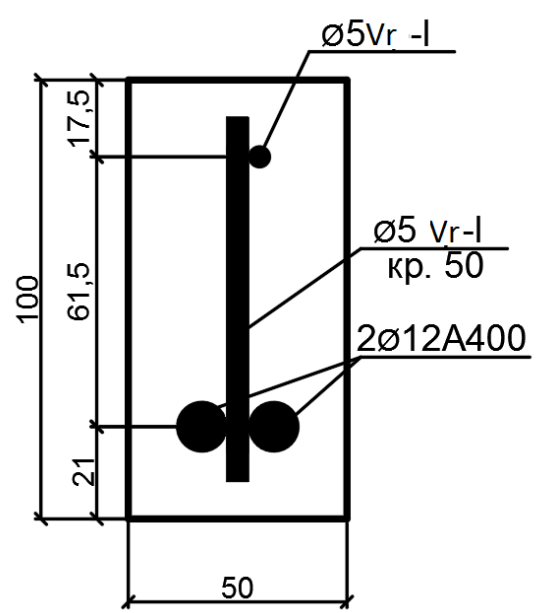

Fig.4. Cross section of experimental beams

of $50 \mathrm{~mm}$ in the supporting zones with a length of $400 \mathrm{~mm}$ The samples were made of concrete, consisting of: granite crushed stone (fractions $5 \ldots 10$ and $10 \ldots 20 \mathrm{~mm})$, quartz sand $(0,95 \mathrm{~mm}$ grain size module), M500 cement, metakaolin additive, and hyperplasticizer (STACHEMENT 2597), water (W/C $=0,32)$. The composition of concrete in each series is different in the amount of cement, metakaolin and W/C 0,35. The characteristics of the concrete of the researched beams are given in Table 2 .

The beams were rested on two supports with a span of $1000 \mathrm{~mm}$ and loaded with two concentrated forces, which were located at a distance of $333 \mathrm{~mm}$ from the supports (Figs 5 and 6).

At each loading stage, the deflections of the beam were measured using a clock type indicator I-1 with the graduation of $0,01 \mathrm{~mm}$.

Concrete deformations in the compressed and stretched zones were measured by indicators of the clock type I-2-I-5 with the graduation of $0,001 \mathrm{~mm}$ on the basis of 200 $\mathrm{mm}$ and strain gauges T-5-T-14 on the basis of $50 \mathrm{~mm}$. The deformations of the reinforcing rods were measured by $\mathrm{T}-1-\mathrm{T}-4$ strain gauges

Table 2. Results of tests of different compositions of concrete for the production of experimental beams

\begin{tabular}{|c|c|c|c|}
\hline Series & $\begin{array}{c}\text { Cubic strength } \\
\mathrm{f}_{\mathrm{ck}, \mathrm{cub},}, \mathrm{MPa}\end{array}$ & $\begin{array}{c}\text { Prism strength } \\
\mathrm{f}_{\mathrm{ck}, \mathrm{prism}}, \mathrm{MPa}\end{array}$ & $\begin{array}{c}\text { Initial modulus of } \\
\text { elasticity } \\
\mathrm{E}_{\mathrm{c}} \times 10^{-3}, \mathrm{MPa}\end{array}$ \\
\hline B-I & 31,45 & 22,86 & 26,47 \\
\hline B-II & 79,50 & 71,14 & 37,42 \\
\hline B-III & 85,05 & 79,51 & 42,83 \\
\hline
\end{tabular}

Table 3. Results obtained when testing experimental beam samples

\begin{tabular}{|c|c|c|c|c|c|}
\hline \multirow[t]{2}{*}{ Series } & \multirow{2}{*}{$\begin{array}{l}\text { Beam's } \\
\text { grade }\end{array}$} & \multicolumn{2}{|c|}{$\begin{array}{c}\text { Cracking load } \\
\mathrm{F}_{\mathrm{crc}, 1}, \mathrm{KH}\end{array}$} & \multicolumn{2}{|c|}{ Destructive loadF $_{\mathrm{u}, 1}, \mathrm{\kappa H}$} \\
\hline & & one sample & average & one sample & average \\
\hline \multirow{4}{*}{ B-I } & B -I-1 & 8,1 & \multirow{4}{*}{7,3} & 13,5 & \multirow{4}{*}{10,75} \\
\hline & B -I-2 & 6,0 & & 10,0 & \\
\hline & B -I-3 & 6,2 & & 10,0 & \\
\hline & B -I-4 & 8,9 & & 9,5 & \\
\hline \multirow{4}{*}{ B-II } & B -II-1 & 6,7 & \multirow{4}{*}{6,4} & 11,5 & \multirow{4}{*}{11,05} \\
\hline & B -II-2 & 6,0 & & 11,0 & \\
\hline & B -II-3 & 6,1 & & 10,8 & \\
\hline & B -II-4 & 6,8 & & 10,9 & \\
\hline \multirow{4}{*}{ B-III } & B -III-1 & 4,6 & \multirow{4}{*}{5,1} & 11,5 & \multirow{4}{*}{13,03} \\
\hline & B -III-2 & 5,1 & & 13,5 & \\
\hline & B -III-3 & 5,9 & & 12,9 & \\
\hline & B -III-4 & 4,8 & & 14,2 & \\
\hline
\end{tabular}


on the basis of $20 \mathrm{~mm}$. The width of the crack opening was measured using a Brinell microscope with the graduation of $0.05 \mathrm{~mm}$. The load was applied with the help of a hydraulic jack through the system of traction and traverse, and the value of force F1 was determined using a dynamometer of the tuning-fork type, which was installed on one of the supports (Figs.5 and 6).

As a result of testing the experimental beams, there were obtained values of the loads Fcrc, 1, at which normal cracks appeared and loads $\mathrm{Fu}, 1$, at which the beams were destroyed. The values of these loads for each beam and their average values for each series are given in Table 3 .

Analysis of the test results showed that the cracks in the high-strength concrete beams (Series B-III) appeared earlier than in the beams of the B-II and B-I series, that is, on average, with $F_{\text {crc }}, 1=5,1 \mathrm{kN}$. It is $19,6 \%$ less than the crack resistance of the B-II series beams $\left(F_{\mathrm{crc}}, 1=6,4 \mathrm{kN}\right)$ and $31,0 \%$ less than the crack resistance of the B-I series beams $\left(F_{\text {crc }}, 1=7,3 \mathrm{kN}\right)$. The analysis of the destructive loads showed quite opposite values, the smallest values were in the beams of the B-I series, i.e. $F_{\mathrm{u}}, 1=10,75 \mathrm{kN}$. It is $2,7 \%$ less

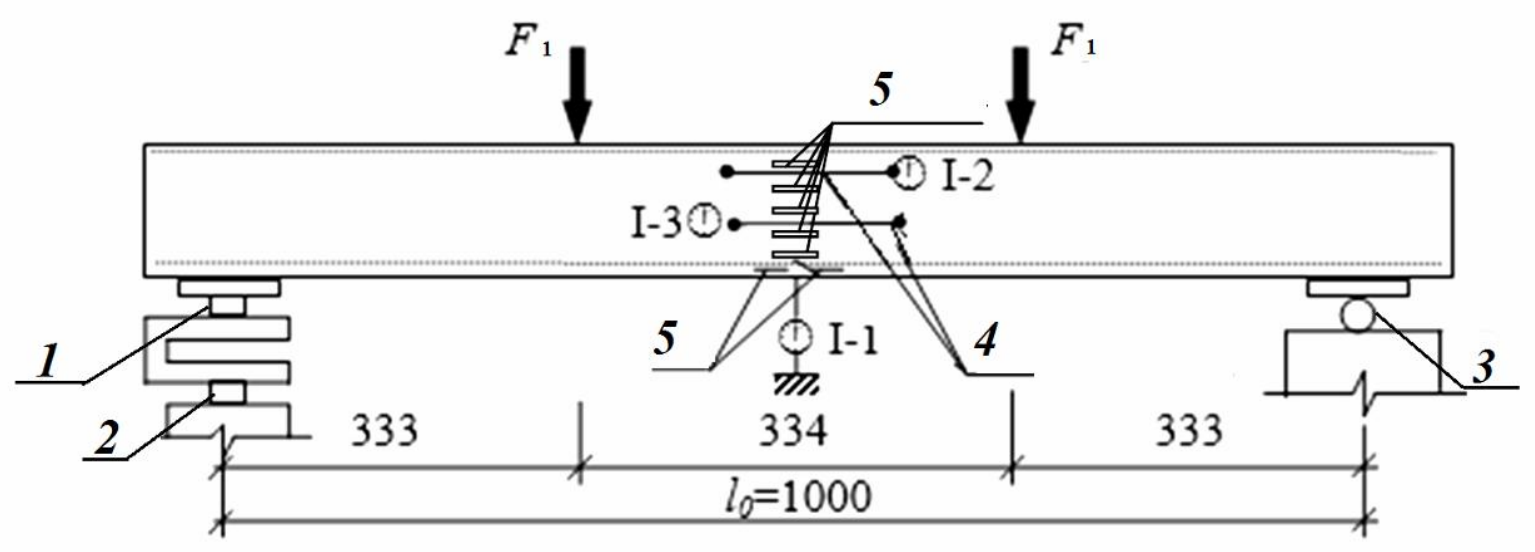

Fig.5. Test scheme of experimental beams: 1 - dynamometer, 2 - fixed support, 3 - movable support, 4 - indicators with a base of $200 \mathrm{~mm}, 5$ - strain gauges

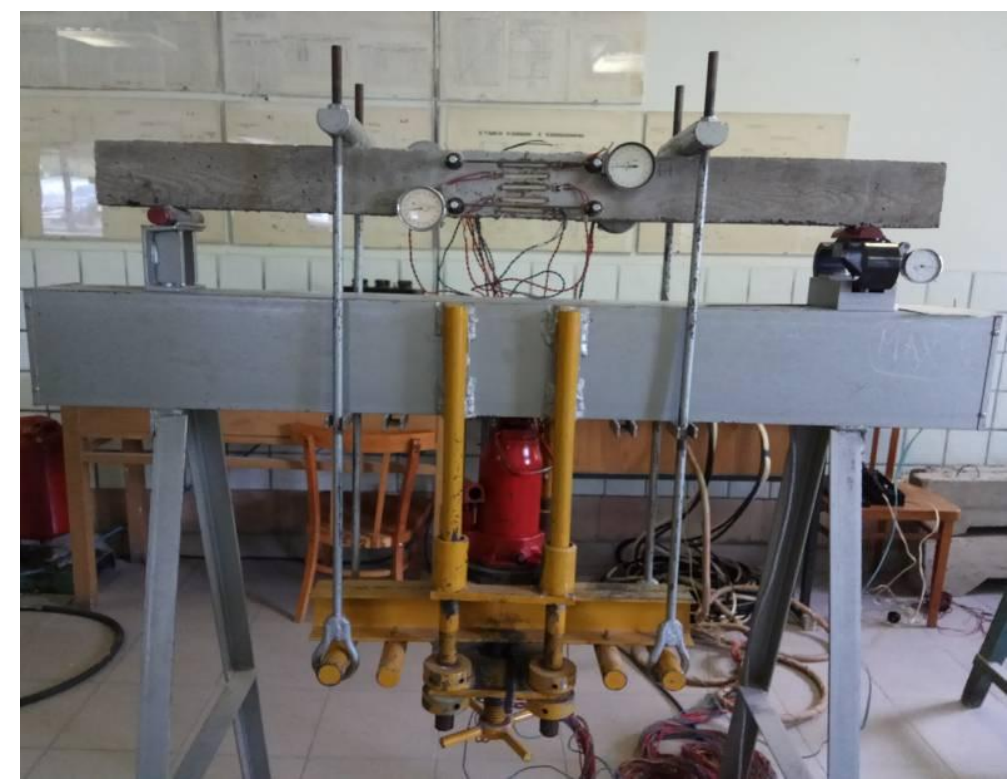

Fig.6. Bench for testing experimental beams 
than the strength of the B-II series beams $\left(F_{\mathrm{u}}\right.$, $1=11,05 \mathrm{kN})$ and $17,5 \%$ less than the strength of the B-III series beams $\left(F_{\mathrm{u}}, 1=13,03 \mathrm{kN}\right)$.

The general appearance of the beams after the test and the nature of the cracking patterns are shown in Figs. $4-6$. Cracking and the nature of destruction of the beams of the B-I series occurred according to the usual scheme- the emergence of normal cracks in the stretched zone of the cross section, their development with increasing load, the destruction of beams as a result of the deformation of the flow of stretched armature and destruction of the compressed zone of concrete (Fig.7). Destructions had a plastic character. Cracking and destruction of the

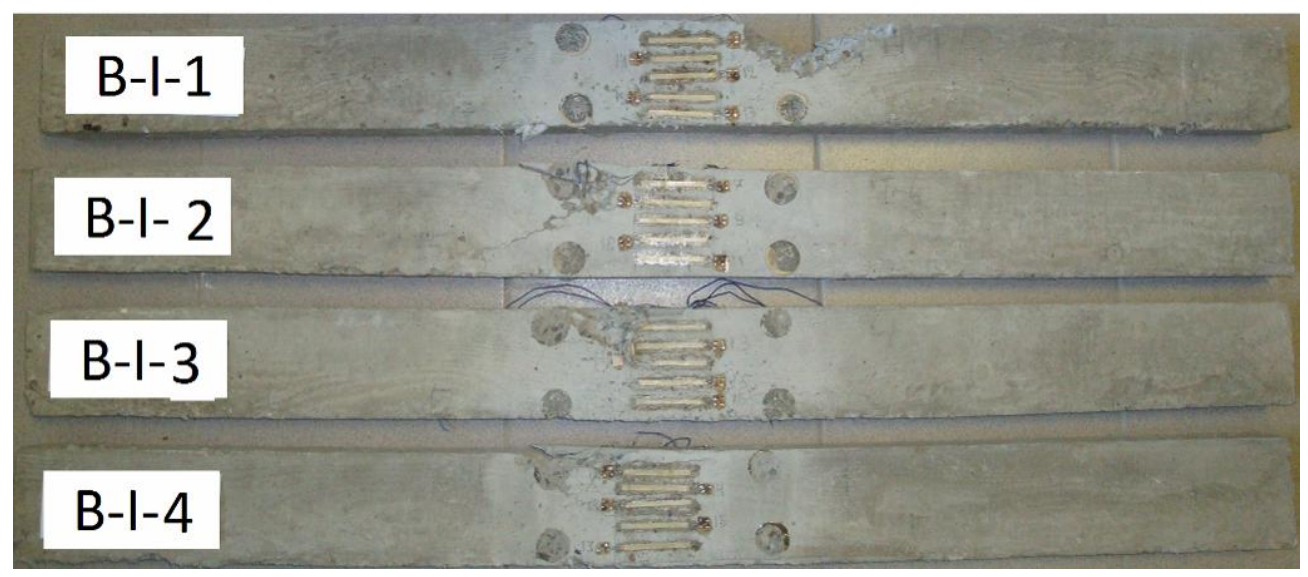

Fig.7. Beams of the B-I series after the test

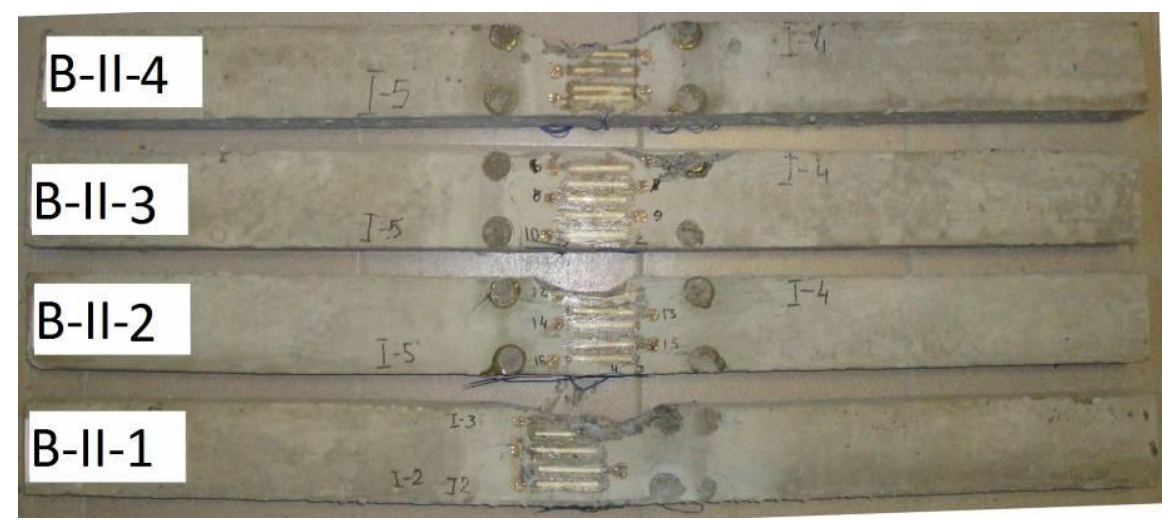

Fig.8. Beams of the B-II series after the test

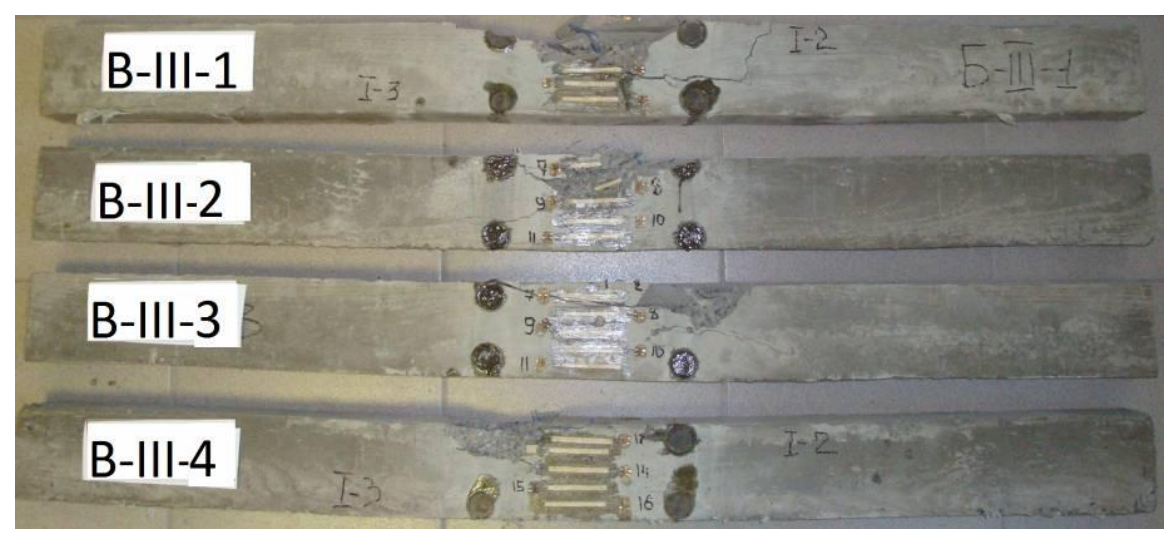

Fig.9. Beams of the B-III series after the test 
beams of B-II and B-III series had somewhat different character (Figs.8, 9). The emergence of cracks began earlier than in the beams of the B-I series. However, their development and disclosure was not as intense as in the beams of the B-I series. During the destruction of beams, the height of the compressed zone was much larger than that of the B-I series. In addition, there were horizontal cracks that separated the stretched and compressed concrete zone.

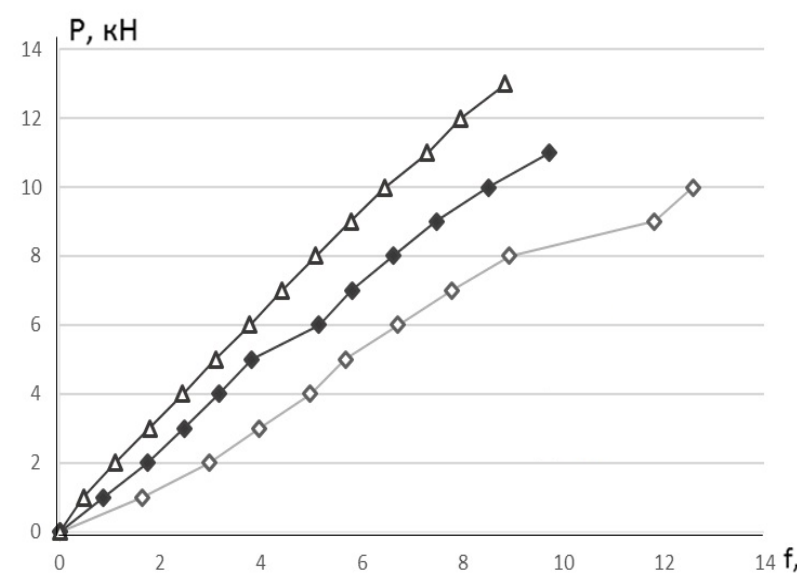

Fig.10. Schedule of averaged indicators:

$\checkmark-$ deflection of beams of series B-I (C20);

$\smile-$ deflection of beams of series B-II (C60);

$\triangle-$ deflection of beams of series B-III (C80)

In Fig.10, we can see that the indices of deflections of concrete grade $\mathrm{C} 20$ are much smaller, at least $30 \%$ lower than the concretes of classes C60 and C80. And the graphs of the C60 and C80 deflections are more linear.

\section{CONCLUSIONS}

1. Having analyzed the use of high-strength concrete, it is possible to highlight the following advantages: reduction in weight and size of the structure; reduction of concrete and reinforcement expenses; higher wear resistance; higher water - and gas resistance. There are very few examples of using highstrength concrete in Ukraine, so this issue is of current interest. Based on the world-wide experience of using high-strength concrete, it is necessary to develop structures on the basis of this concrete, to improve the methods of calculation and design.

2. Experimental researches of reinforced concrete beams made of high-strength and traditional concrete showed some differences in their operation in transverse bending. This will enable to improve the method of calculation of bending reinforced concrete elements of high-strength concrete.

\section{REFERENCES}

1. Nehdi R. M., Mindness S. \& Aitcin P.C., 1998. Rheology of high performance concrete: Effect of ultrafine particles. Cement and Concrete Research, 28(5), 687-697.

2. Berg O.J., Shcherbakov E.N., Pisanko G.N. 1971. High-strength concrete. Moskow: Stroyizdat, 196.

3. Kutsyk O.V., Zhuravsky O.D., 2016. Analysis of the use of high-strength concrete in modern construction. Urban Planning and Territorial Planning: Science. Tech. collection. Kyiv, KNUCA, Iss.61, 444-449.

4. Kutsik O., 2017. Efficiency of using highstrength concrete. Build-master-class-2017, III International conference 2017, 181-182.

5. Kutsyk O.V., Zhuravsky O.D., 2017. Strength and crack resistance of bent elements of highstrength concrete. Building Constructions. Theory and Practice, Iss. 1, 199-204

6. Abbas R., Abo-El-Enein S.A. \& Ezzat E.S., 2010. Properties and durability of metakaolin blended cements: Mortar and concrete. Materiales De Construccion, 60, 33-49.

7. Wild S., Khatib J.M. \& Jones A., 1996. Relative strength, pozzolanic activity and cement hydration in superplasticised metakaolin concrete. Cement and Concrete Research, 26(10), 1537-1544.

8. Badogiannis E. \& Tsivilis S., 2009. Exploitation of poor Greek kaolins: Durability of metakaolin concrete. Cement \& Concrete Composites, 31(2), 128-133.

9. Tiwari A.K. \& Bandyopadhyay P., 2003. High performance concrete with Indian metakaolin. In International symposium on innovative world of concrete, 19-21 September. Pune: Indian Concrete Institute.

10. Basu P.C., 2003. High performance concrete. In Proceedings INAE national seminar on 
engineered building materials and their performance, 426-450.

11. Kuprienko P., Lapovska S., Kuprienko N., 2017. Nanomodified natural aluminum silicates in technology treatment of industrial waste and the production of building materials. Underwater Technologies, Iss.5, 74-83.

12. Basu P.C., Mavinkurve S., Bhattacharjee K. N., Deshpande, Y. \& Basu, S., 2000. High reactivity metakaolin: A supplementary cementitious material. In Proceedings ICIAsian conference on ecstasy in concrete, 20-22 Nov, Bangalore, India, 237-436.

13. Boddy A., Hooton R.D., \& Gruber K.A., 2001. Long-term testing of the chloridepenetration resistance of concrete containing high-reactivity metakaolin. Cement and Concrete Research, 31, 759-765.

14. Dvorkin L., Bezusyak A., Lushnikova N., \& Ribakov Y., 2012. Using mathematical modelling for design of self compacting high strength concrete with metakaolin admixture. Construction and Building Materials, 37, 851864.

15. Guneyisi E., Gesoglu M., \& Mermerdas K., 2008. Improving strength, drying shrinkage, and pore structure of concrete using metakaolin. Materials and Structures, 41, 937-949.

16. Haque M.N., \& Kayali O., 1998. Properties of high strength concrete using a fine fly ash. Cement and Concrete Research, 28(10), 14451452.

17. Poon C.S., Lam L., Kou S.C., Wong Y.L. \& Wong R., 2001. Rate of pozzolanic reaction of metakaolin in high-performance cement pastes. Cement and Concrete Research, 31(9), 13011306.

18. Mehta P.K., \& Monteiro P.J., 1999. Concrete: microstructure, properties, and materials. Delhi, India: Indian Concrete Institute.

\section{Эффективность использования высокопрочного бетона в железобетонных конструкциях}

\section{Olena Kutsyk}

Аннотация. Выполнен анализ использования современных высокопрочных бетонов в мировой практике. Проанализированы преимущества и недостатки высокопрочных бетонов. Рассмотрены уже существующие примеры реализации в мире высокопрочного бетона и их виды и сферы применения. Определены перспективы использования высокопрочных бетонов в строительной отрасли Украины. Использование качественных материалов для изготовления несущих конструкций высотного строительства, и строительства мостов, тоннелей и других высоко ответственных зданий и сооружений. Эффективным и перспективным для обеспечения всех потребностей является высокопрочный бетон который обладает высокой прочностью, водо- и газонепроницаемостью, корозостийкистю за счет своей однородной структуры. В данной работе был разработаны и испытаны экспериментальные образцы кубиков, призм, балок для определения и рассмотрения эффективности использования высокопрочного бетона в згибаемых элементов.

В данной статье представлении экспериментальные результаты проведения данных по подбору эффективного состава бетонной смеси, и предоставлены экспериментальные образцы с характерными разрушениями. На образцах кубиков можно увидеть принципы разрушения классов С20 где нормальные разрушенияб а классов С60 и С80 уже наблюдается хрупкий характер разрушения. Также были предоставлены результаты разрушений призм классов C20, С60 и С80 где также представлены примеры разрушении определения модули упругости образцов. В объединении таблицы было приведены кубиковые и призменные прочность, что показывает эффективность применения высокопрочного бетона по сравнению с традиционными бетонами, поскольку в бетонах повышается прочность на сжатие так и повышаются относительно прочность на растяжение, плотность, снижается пористость и в целом улучшается структура. Приведенные результаты экспериментальных исследований прочности и трещиностойкости железобетонных балок из высокопрочного бетона и выполнено сравнение их с балками из обычного бетона.

Ключевые слова: высокопрочный бетон, пластичность, прочность, трещиностойкость, прогибы, модуль упругости. 